\title{
Research Barriers from the Viewpoints of Faculty Members of a Military University of Medical Sciences
}

\author{
Somayeh Azarmi, ${ }^{1}$ Shahla Aliyari, ${ }^{1,}{ }^{*}$ Armin Zareian, ${ }^{1}$ and Simintaj Sharififar ${ }^{1}$ \\ ${ }^{1}$ Faculty of Nursing, AJA University of Medical Sciences, Tehran, IR Iran \\ "Corresponding author: Shahla Aliyari, Faculty of Nursing, AJA University of Medical Sciences, Tehran, IR Iran. E-mail: aliyar_shah@yahoo.com
}

Received 2018 February 06; Revised 2018 June 02; Accepted 2018 June 04.

\begin{abstract}
Background: Emphasis on research issues and increased research activities leads to development and progress and brings about real self-sufficiency and independence for a country. The purpose of this study was to identify the failures and barriers of research at AJA University of Medical Sciences.

Methods: The methodology of this study was cross-sectional (descriptive-analytic) and was conducted at AJA University of Medical Sciences of Iran. Sampling was census and 85 faculty members participated in this study. The instrument was a valid and reliable questionnaire in two parts. The first part was about demographic information and the second part focused on the research barriers with 53 items.

Results: The findings revealed that the highest percentage of research barriers was related to financial barriers from the viewpoints of the subjects and the lowest percentage was related to individual barriers.

Conclusions: A set of factors influenced the research activities of faculty members. Financial issues were significant among these factors.
\end{abstract}

Keywords: Medical, Faculty, Research, Universities

\section{Background}

Research is considered as the main pillar of sustainable cultural, social, and economic development, and the assumption of long-term development is impossible without the establishment of a coherent research system (1). Hence, emphasis on research issues and increased research activities leads to development and progress and brings about real self-sufficiency and independence for a country (2-5). In Iran, about half a percent of GDP is spent on research (6), while the share of research credits from GDP in European countries has been on average more than two percent (7).

The major part of research activities and scientific production are conducted by faculty members of universities; hence, if they provide their services with better quality, the scientific development and progress of the country will be accelerated (8). The AJA University of Medical Sciences has been active in providing conditions and facilities, which are essential for research, including establishment of research institutions, selection of top researchers, and special attention to the institute of military medicine. However, the current situation and the number of researches conducted by faculty members is not satisfactory.

Understanding research barriers is an essential tool that should be made available to decision makers, through which they can make decisions to achieve goals, improve methods, and increase efficiency (9). Identifying research barriers creates a proper context and an appropriate environment for creativity and innovation at universities. Research along with education is essential for realization of development goals in various dimensions and performing research also requires the removal of research barriers, which is done through their recognition. Considering the importance of the issue and the need for performing such research at all universities of the country as well as the lack of a comprehensive studies on the identification of research barriers at AJA University of Medical Sciences, in this study, the researchers attempted to examine the research barriers from the viewpoint of faculty members of this university as one of the important issues of the research system. In the present study, the questionnaire of the Karimian et al. study was used to assess the barriers of research (10). 


\section{Methods}

The study was a cross-sectional type, conducted in 2013 at AJA University of Medical Sciences of Iran. The statistical population included faculty members of AJA Medical University. Sampling was done by the census method. Among 114 faculty members, 85 from the faculties of medicine (54), dentistry (5), nursing (13), aerospace (2), and paramedicine (11) participated in the study. The inclusion criteria were being an approved faculty member and a full-time professor. The research instrument was a questionnaire developed by the researcher in two parts. The first part was about demographic information (age, gender, scientific degree, educational qualification, service record, faculty of service, and the number of credits taught in the last semester). The second part focused on the research barriers. The questionnaire of the research barriers was derived from the Karimian et al. study (10).

However, due to changes in the questionnaire, its validity and reliability were re-evaluated in this study. The research barriers were in the form of 46 initial statements and six categories. The statements were reexamined by the researcher and co-workers according to the conditions and issues at the university. After applying necessary changes and modifications, the statements were increased to 56 . The content validity of the questionnaire was another issue that was considered. To this end, the views of ten experts were used and the questionnaire insufficiencies were resolved according to their opinions. Also, the internal consistency (Cronbach alpha) was used to determine the reliability. Therefore, the questionnaire was completed by 21 faculty members to confirm the internal reliability in a pilot study. The Cronbach alpha coefficient was 0.9. The alpha coefficients of the studied domains were also as follows: Financial barriers (0.86), facilities barriers (0.67), professional barriers (0.73), scientific barriers (0.85), individual barriers (0.52), and organizational-managerial barriers (0.70).

The final questionnaire with 53 items in a four-point Likert scale (agree, rather agree, rather disagree, disagree) and in six financial (seven items), facilities (ten items), professional (nine items), scientific (seven items), individual (five items) and organizational-managerial (15 items) categories was designed. The questionnaires were dispersed among faculty members and followed up by phone calls. Finally, 85 questionnaires were returned and 29 faculty members did not fill the questionnaire. The SPSS version 20 software was used to analyze the data, and descriptive statistics and inferential statistics (independent t-test and ANOVA test) were employed for statistical analysis. In addition, a significance level of $\mathrm{P}<0.05$ was considered. The principles set forth by the declaration of Helsinki were ob- served in the research (11).

\section{Results}

The distribution of absolute and relative frequencies of demographic variables are presented in Table 1 . The results obtained from the viewpoints of the studied subjects in terms of degree of agreement to be a research barrier of each of the different dimensions of the research barriers are given in Table 2. The presence of six barriers, namely financial (82.4\%), facilities (58.8\%), professional (62.4\%), scientific (24.7\%), individual (23.5\%), and organizational-managerial $(28.2 \%)$ were demonstrated in this study. The findings revealed that the highest percentage of research barriers were related to financial barriers from the viewpoints of the subjects and the lowest percentage were related to individual barriers.

\begin{tabular}{|c|c|}
\hline Variable/Subgroup & No. (\%) \\
\hline \multicolumn{2}{|l|}{ Gender } \\
\hline Female & $40(47.1)$ \\
\hline Male & $45(52.9)$ \\
\hline \multicolumn{2}{|l|}{ Academic rank } \\
\hline Instructor & $23(27.7)$ \\
\hline Assistant Professor & $56(67.5)$ \\
\hline Associate Professor & $4(4.8)$ \\
\hline Professor & $0(0)$ \\
\hline \multicolumn{2}{|l|}{ Faculty of service } \\
\hline Medical & $54(63.5)$ \\
\hline Dentistry & $5(5.9)$ \\
\hline Nursing & $13(15.3)$ \\
\hline Paramedical & $11(12.9)$ \\
\hline Aerospace & $2(2.4)$ \\
\hline \multicolumn{2}{|l|}{ Educational qualification } \\
\hline Master of science & $21(24.7)$ \\
\hline General practitioner & $3(3.5)$ \\
\hline Specialist & $32(37.6)$ \\
\hline Subspecialty & $10(11.8)$ \\
\hline $\mathrm{PhD}$ & $19(22.4)$ \\
\hline
\end{tabular}

In examining demographic variables individually in faculty members' viewpoint of research barriers, the results of the ANOVA test showed a significant difference between the educational qualification of the study units regarding the research scientific barriers $(\mathrm{P}=0.029)$ (Table 3). However, there was no significant difference between 
educational qualifications of the studied units in terms of other research barriers. In terms of other variables, such as gender, scientific degree and faculty of service, there was no significant statistical difference in any of the dimensions of research barriers $(\mathrm{P}>0.05)$.

\section{Discussion and Conclusions}

Analyzing viewpoints of faculty members in this study revealed that doing research at AJA University of Medical Sciences was affected by several barriers and problems, which can be considered and addressed from different aspects. In the present research, the faculty members suggested that the research financial barriers were more effective than other research barriers. In most conducted studies, including Hoseiny and Jahed (12) and Karimian (10), the financial difficulties and economic barriers were much more significant than other barriers. Majumdar (13) also mentioned economic and financial barriers in his study as the most important problem in developing Asian countries.

In this study, the subjects mentioned a lack of funding for academic and research activities at the university as the most important financial barrier. Most scholars also agreed on the lack of funding in research activities and the inadequacy of the budget as the most important problem in the field of research (14). In his study, Dadkhah et al. (4) also reported a low research grant compared to the time spent on the research as one of the major obstacles in the view of faculty members, which is consistent with the results of the current research. In Vahdati et al. study (1), the most significant research barriers were mentioned to be professional barriers, which is not consistent with the results of this research.

The highest percentage of facility barriers dimensions of the present research was related to poor speed and bandwidth of the Internet at the university. However, it was found in Naghizadeh Baghi et al. study (15) that factors involved in the preparation and design of the research project and the researcher's lack of access to information are less important among the research barriers. Also, in studies by Majumdar (13), Sumathipala et al. (16), and Salem Safy et al. (17), the shortage of research equipment and facilities were mentioned. In a study by Karimian et al. (10), difficulty and the time-consuming process of supplying the necessary materials were reported as the main facility barriers. These results are not consistent with the present study.

The most frequent professional barrier in the present study was the inability to have a close scientific communication with researchers and research centers overseas, while in many studies, the shortage of time factor due to the employment of executive activities has been raised as the most important research professional barrier $(1,10)$. A work overload and different expectations from the faculty members were also reported as the most important research barriers in various universities (18-21).

In this study, the professors demanded further skills in writing articles, providing posters and publishing, and presenting them to journals and scientific assemblies inside and outside the country. This was introduced as the most important scientific research barrier from the viewpoint of the research subjects. In Hashemi et al. (22) and Sereshti et al. (23) studies, scientific barriers, such as the lack of necessary knowledge on the research methodologies and statistical methods and the lack of mastery of foreign languages were raised as scientific barriers for the researchers.

In the present study, individual barriers were reported as the least research barriers from the viewpoint of the subjects, while in his study, Hosseinpour (24) stated that individual barriers were the most inhibiting factor in the research. Lack of motivation and sufficient interest to conduct research was revealed as the most frequent research individual barrier in this study. In Rahimi's study (25), the impact of the internal motivations of individuals on their level of research activities was confirmed. However, in the study conducted by Badrizadeh et al. (21), the most frequent individual barriers, included a lack of time due to long hours of teaching and social and executive responsibilities, while the least frequent individual barriers were related to the lack of interest in research affairs and not having enough experience in writing articles and drafting proposals, which are not consistent with the present study.

The most important organizational-management barrier in the current research was mentioned as the longrun and slow stages of papers being accepted for publication in domestic and foreign journals. In a research by Badrizadeh et al. (21), the stringency in the approval of the researcher's favorite projects and administrative abstinence in conducting research and the long process of approval of research projects were reported as the most significant organizational obstacle.

In separately evaluating the faculty members' viewpoints, it was shown that there was no significant difference between the two groups of females and males in terms of any of the research barriers dimensions. However, in a study by Karimian et al. (10), there were significant differences between faculty views in terms of professional, individual, and organizational-managerial barriers by gender. There was a significant difference between degrees of education of the research units in terms of research scientific barriers. In summary, the highest percentage of agreement in terms of scientific barriers was re- 


\begin{tabular}{|c|c|c|c|c|c|c|c|}
\hline \multirow[b]{2}{*}{ Educational Qualification } & \multirow[t]{2}{*}{$\mathbf{N}$} & \multicolumn{6}{|c|}{ Research Barriers } \\
\hline & & Financial & Facilities & Professional & Scientific & Individual & Organizational-Managerial \\
\hline Master of Science & 21 & $3.49 \pm 0.37$ & $3.17 \pm 0.42$ & $3.47 \pm 0.39$ & $2.62 \pm 0.56$ & $2.91 \pm 0.40$ & $2.88 \pm 0.42$ \\
\hline General practitioner & 3 & $3.38 \pm 0.73$ & $3.20 \pm 0.10$ & $3.29 \pm 0.23$ & $3.42 \pm 0.51$ & $3.33 \pm 0.41$ & $3.28 \pm 0.10$ \\
\hline Specialist & 32 & $3.72 \pm 0.40$ & $3.37 \pm 0.46$ & $3.29 \pm 0.52$ & $3.01 \pm 0.64$ & $2.99 \pm 0.53$ & $3.16 \pm 0.50$ \\
\hline Subspecialty & 10 & $3.53 \pm 0.40$ & $3.17 \pm 0.36$ & $3.05 \pm 0.48$ & $2.50 \pm 0 / 61$ & $2.82 \pm 0.51$ & $2.77 \pm 0.46$ \\
\hline PhD & 19 & $3.56 \pm 0 / 38$ & $3.24 \pm 0.42$ & $3.43 \pm 0.31$ & $2.69 \pm 0.66$ & $2.97 \pm 0.53$ & $2.93 \pm 0.35$ \\
\hline \multicolumn{8}{|l|}{ ANOVA test } \\
\hline df & & 4,80 & 4,80 & 4,80 & 4,80 & 4,80 & 4,80 \\
\hline Ftest & & 1.413 & 0.916 & 1.844 & 2.862 & 0.694 & 2.478 \\
\hline P Value & & 0.237 & 0.459 & 0.128 & $0.029^{*}$ & 0.598 & 0.051 \\
\hline
\end{tabular}

${ }^{\mathrm{a}}$ Values are expresses as mean $\pm \mathrm{SD}$.

lated to faculty members with doctoral degrees. No significant difference was found in case of academic rank and faculty of service of the subjects in terms of any dimensions of the research barriers. In the study by Karimian et al. (10), there was a significant difference between academic field groups in terms of research scientific barriers, which is not consistent with the results of the present study. In addition, a significant difference was found between the faculty members' views on professional, individual, and organizational-managerial barriers, according to the academic rank. Accordingly, the instructors showed higher average barriers compared to professors and associate professors. The results of a study by Tien (26) also suggested that the instructors had lower research efficiency compared to the associate professors.

The results of this study indicated that a set of factors influenced the research activities of faculty members, which can be generalized only to AJA University of Medical Science and may vary from one university to another, where other barriers may be prioritized.

Also, the barriers to research in this study were examined purely from the viewpoint of faculty members at a certain time period. Thus, the viewpoints of faculty members toward the university research barriers need to be evaluated at different times. In addition, the viewpoints of other groups, such as students of different degrees of education should be considered. The limitations of this research included the dispersion of faculty members in the educational, medical, and faculty departments, who were very busy at work, and this prolonged the process of distributing and collecting the questionnaires.

\section{Acknowledgments}

This article was the result of a research project approved by AJA University of Medical Science. The authors would like to appreciate all officials and the faculty members of this university. Acknowledgements The authors would like to appreciate all officials and the faculty members of AJA University of Medical Sciences, who, in spite of a lot of busy work, kindly participated in this study.

\section{Footnotes}

Authors' Contribution: Shahla Aliyari was responsible for the study conception and design. Somayeh Azarmi, Shahla Aliyari, and Armin Zareian performed the data collection and analysis. Shahla Aliyari was responsible for the drafting of the manuscript. Shahla Aliyari, Somayeh Azarmi, and Simintaj Sharififar were responsible for critical revisions of the paper for important intellectual content.

Conflict of Interests: No conflict of interest was declared by the authors.

Funding/Support: This article was the result of a research project approved by the AJA University of Medical Science and supported by this university.

\section{References}

1. Vahdati M, Mazloomy SS, Salimi T, Eghbal A. A survey on educational research barriers in Shahid Sadoughi University of Medical Sciences in 2014. J Med Educ Dev. 2014;9(2):33-40.

2. Kazemi Malekmahmoudi S. The Research barriers at University from students' point of view in Golestan University of Medical Sciences. Educ Dev Jundishapur. 2016;7(1):84-93. 
3. M S. Pathology of Obstacles to performing research among faculty members and providing practical solutions. J Educ Administ Res Q. 2011;3(1):45-60.

4. Dadkhah B, Mohammadi M, Poornaseri S, Mozaffari N, Adham D. View of Ardabil province universities scientific members' about research and its limitations. J Ardabil Univ Med Sci. 2008;8(1):37-44.

5. Alamdari AK, Afshoun E. The view point of faculty members on research barriers at Yasuj Universities. 2003.

6. Saber A. Scientific Documents of Iran in the 2015 year. J Neshae Elm. 2016;6(2):92-102.

7. Lopez AH, Bourgeais V. First estimates of Research and Development expenditure R and D expenditure in the EU stable at slightly over $2 \%$ of GDP in 2014 Almost two thirds spent in the business sector European Commission. Eurostat Press Office; 2015.

8. Ebrahimzade FNJ, Ghorbani M, Almasi A. The study of barriers to research from the point of view of professors of Lorestan University of Medical Sciences and its relevance to its research performance. $J$ Lorestan Univ Med Sci. 2016;18(1):28-41.

9. Aronestam RS, Freije JE. Physician participation in clinical research at guthric health. Guthrie J. 2003;721(3):66-71.

10. Karimian Z, Sabbaghian Z, Saleh Sedghpour B, Lotfi F. Internal obstacles in research activities: faculty members' viewpoints in Shiraz University of Medical Sciences. Iran J Med Educ. 2012;11(7):750-63.

11. Grove SK, Burns N, Gray J. The practice of nursing research: Appraisal, synthesis, and generation of evidence. Elsevier Health Sciences; 2012.

12. Hoseiny SA, Jahed $H$. The Viewpoint of faculty members on research obstacles at Tabriz University. J Sci Technol Policy. 2012;4(4):49-64.

13. Majumder MA. Issues and priorities of medical education research in Asia. Ann Acad Med Singapore. 2004;33(2):257-63. [PubMed:15098645]

14. Jurablo M. Software movement. Tehran: Elaheye Naz; 2004.

15. Naghizadeh Baghi A, Khanbabazadeh Ghadim M, Samari E. Survey of barriers and research problems from the viewpoint of faculty members of Ardabil university of medical sciences. J Ardabil Univ Med Sci. 2015;15(3):255-64.

16. Sumathipala A, Siribaddana S, Patel V. Under-representation of developing countries in the research literature: ethical issues arising from a survey of five leading medical journals. BMCMed Ethics. 2004;5. E5. doi: 10.1186/1472-6939-5-5. [PubMed: 15461820]. [PubMed Central: PMC524359].

17. Salem Safy R, Sadatian R, Ashraf Rezaei BN, Moshirie Z, Baniadam A. Evaluation of Urmia Medical University Faculty member views about research obstacles. J Urmia Nurs Midwifery Faculty. 2009;7(3):142-51.

18. Koorki M, Mahjub H, Sheikh N. Study of the academic members attitude about main factors of not approaching to scientific writing in Hamadan university of medical sciences. Sci J Hamadan Univ Med Sci. 2008;14(4):59-63.

19. Farmanbar R, Asgari F. Study of constraining factors of research from the viewpoint of faculty members in Guilan University of Medical Sciences. J Guilan Univ Med Sci. 2005;14(54):84-91.

20. Levine RB, Hebert RS, Wright SM. Resident research and scholarly activity in internal medicine residency training programs. J Gen Intern Med. 2005;20(2):155-9. doi: 10.1111/j.1525-1497.2005.40270.x. [PubMed: 15836549]. [PubMed Central: PMC1490049].

21. Badrizadeh A, Gholami Y, Birjandi M, Beiranvand G, Mahooti F. Barriers to research from viewpoint of faculty members of Lorestan university of medical sciences. Yafteh. 2009;11(3):93-100.

22. Hashemi ZMM. Does the degree of faculty members' proficiency in English affect their participation in the production of science? 9th National Conference on Medical Education. Shaheed Sadoughi University of Medical Science Yazd. 2007.

23. Sereshti M, Kazemian A, Daris F. Research barriers from the viewpoint of faculty members and employees of Shahrekord University of Medical Sciences. Educ Strateg Med Sci. 2010;3(2):51-7.

24. Hosseinpour M. A study of debilitating factors of research from the viewpoint of faculty members in human sciences. J Soc Psychol. 2011;6(19):79-95.

25. Rahimi MFR. Investigating the impact on the level of scientific collaboration from the perspective of the Mashhad University faculty. Q Lib Inf Sci. 2009;12(1):79-98.

26. Tien FF. Faculty research behaviour and career incentives: The case of Taiwan. Int J Educ Dev. 2007;27(1):4-17. doi: 10.1016/j.ijedudev.2006.04.014. 
Table 2. Research Barriers from the Viewpoint of Faculty Members of AJA University of Medical Sciences (2015) ${ }^{\mathrm{a}}$

\begin{tabular}{|c|c|c|c|c|c|}
\hline \multirow[t]{2}{*}{ Area } & \multirow[t]{2}{*}{ Statements } & \multicolumn{4}{|c|}{ Scope of Agreement on the Research Barrier } \\
\hline & & Agree & Rather Agree & Rather Disagree & Disagree \\
\hline \multirow{7}{*}{ Financial } & $\begin{array}{l}\text { The research grants are not paid in a timely } \\
\text { manner. }\end{array}$ & $68(80.0)$ & $15(17.6)$ & $1(1.2)$ & $1(1.2)$ \\
\hline & $\begin{array}{l}\text { Funding for academic and research activities at } \\
\text { the university is not enough. }\end{array}$ & $70(82.4)$ & $11(12.9)$ & $2(2.4)$ & $2(2.4)$ \\
\hline & $\begin{array}{l}\text { The rules for budgeting research projects are } \\
\text { not appropriate. }\end{array}$ & $55(64.7)$ & $26(30.6)$ & $3(3.5)$ & $1(1.2)$ \\
\hline & $\begin{array}{l}\text { The extreme bureaucracies are tedious at paying } \\
\text { the expense of research projects. }\end{array}$ & $57(67.1)$ & $23(27.1)$ & $2(2.4)$ & $3(3.5)$ \\
\hline & $\begin{array}{l}\text { The amount of research revenue is negligible } \\
\text { compared to the incomes outside the university. }\end{array}$ & $65(76.5)$ & $15(17.6)$ & $3(3.5)$ & $2(2.4)$ \\
\hline & $\begin{array}{l}\text { Funds and facilities at the university are not } \\
\text { distributed equitably and fairly. }\end{array}$ & $47(55.3)$ & $32(37.6)$ & $5(5.9)$ & $1(1.2)$ \\
\hline & $\begin{array}{l}\text { Sometimes the distribution of research budgets } \\
\text { is affected by individuals' names and influences. }\end{array}$ & $45(52.9)$ & $28(32.9)$ & $9(10.6)$ & $3(3.5)$ \\
\hline Total & Financial barriers & $70(82.4)$ & $14(16.5)$ & $1(1.2)$ & $0(0)$ \\
\hline \multirow{10}{*}{ Facilities } & $\begin{array}{l}\text { The speed and bandwidth of the Internet at the } \\
\text { university is not optimal. }\end{array}$ & $73(85.9)$ & $9(10.6)$ & $2(2.4)$ & $1(1.2)$ \\
\hline & $\begin{array}{l}\text { The university's information and Internet } \\
\text { system are often not available. }\end{array}$ & $60(70.6)$ & $21(24.7)$ & $4(4.7)$ & $0(0)$ \\
\hline & $\begin{array}{l}\text { Access to useful databases at the university is } \\
\text { limited. }\end{array}$ & $50(58.8)$ & $29(34.1)$ & $6(7.1)$ & $0(0)$ \\
\hline & $\begin{array}{l}\text { There are no research centers available to } \\
\text { resolve the problems and uncertainties of } \\
\text { researchers at colleges and universities. }\end{array}$ & $43(50.6)$ & $36(42.4)$ & $4(4.7)$ & $2(2.4)$ \\
\hline & $\begin{array}{l}\text { There are not well-trained and efficient research } \\
\text { assistants and academic research assistants to } \\
\text { translate and transmit Latin papers at the } \\
\text { university. }\end{array}$ & $51(60.0)$ & $27(31.8)$ & $3(3.5)$ & $4(4.7)$ \\
\hline & $\begin{array}{l}\text { The research facilities and equipment are not } \\
\text { sufficient (hardware, computer software, } \\
\text { laboratory equipment, etc.). }\end{array}$ & $49(57.6)$ & $24(28.2)$ & $11(12.9)$ & $1(1.2)$ \\
\hline & Research assistants are not active in schools. & $11(12.9)$ & $33(38.8)$ & $24(28.2)$ & $17(20.0)$ \\
\hline & $\begin{array}{l}\text { Facilities such as type, print, and Xerox are not } \\
\text { available enough. }\end{array}$ & $41(48.2)$ & $26(30.6)$ & $12(14.1)$ & $6(7.1)$ \\
\hline & $\begin{array}{l}\text { Librarians do not collaborate with scholars on } \\
\text { research topics. }\end{array}$ & $10(11.8)$ & $35(41.2)$ & $30(35.3)$ & $10(11.8)$ \\
\hline & $\begin{array}{l}\text { Academic resources of the university are not } \\
\text { enough (specialized library, subscriptions of } \\
\text { scientific journals, full-text articles, documents, } \\
\text { etc.). }\end{array}$ & $38(44.7)$ & $27(31.8)$ & $19(22.4)$ & $1(1.2)$ \\
\hline Total & Facilities barriers & $50(58.8)$ & $30(35.3)$ & $5(5.9)$ & $0(0)$ \\
\hline \multirow{7}{*}{ Professional } & $\begin{array}{l}\text { There are many barriers to attending seminars } \\
\text { and conferences abroad. }\end{array}$ & $65(76.5)$ & $14(16.5)$ & $3(3.5)$ & $3(3.5)$ \\
\hline & $\begin{array}{l}\text { Livelihood problems: Faculty members require } \\
\text { having several careers outside the university. }\end{array}$ & $57(67.1)$ & $12(14.1)$ & $12(14.1)$ & $4(4.7)$ \\
\hline & $\begin{array}{l}\text { There is no close link between the domestic } \\
\text { university and other universities and the } \\
\text { research centers. }\end{array}$ & $51(60.0)$ & $27(31.8)$ & $7(8.2)$ & $0(0)$ \\
\hline & $\begin{array}{l}\text { The close scientific relationship with } \\
\text { researchers and research centers abroad is not } \\
\text { easily possible. }\end{array}$ & $66(77.6)$ & $16(18.8)$ & $0(0)$ & $3(3.5)$ \\
\hline & $\begin{array}{l}\text { Acceptance and publication of research papers } \\
\text { in international and ISI magazines are difficult } \\
\text { due to the country's political and international } \\
\text { relations. }\end{array}$ & $38(44.7)$ & $34(40.0)$ & $8(9.4)$ & $5(5.9)$ \\
\hline & $\begin{array}{l}\text { Several executive responsibilities at the } \\
\text { university do not leave much time for research. }\end{array}$ & $47(55.3)$ & $20(23.5)$ & $10(11.8)$ & $8(9.4)$ \\
\hline & $\begin{array}{l}\text { The use of research-study opportunities is very } \\
\text { limited and difficult. }\end{array}$ & $56(65.9)$ & $23(27.1)$ & $4(4.7)$ & $2(2.4)$ \\
\hline
\end{tabular}




\begin{tabular}{|c|c|c|c|c|c|}
\hline & $\begin{array}{l}\text { The high volume of health and medical work do } \\
\text { not leave much time for research. }\end{array}$ & $38(44.7)$ & $27(31.8)$ & $17(20.0)$ & $3(3.5)$ \\
\hline & Required teaching hours are high for professors. & $15(17.6)$ & $30(35.3)$ & $28(32.9)$ & $12(14.1)$ \\
\hline Total & Professional barriers & $53(62.4)$ & $28(32.9)$ & $4(4.7)$ & $0(0)$ \\
\hline \multirow{7}{*}{ Scientific } & $\begin{array}{l}\text { Academic professors do not have sufficient } \\
\text { mastery of developing a research proposal. }\end{array}$ & $16(18.8)$ & $45(52.9)$ & $19(22.4)$ & $5(5.9)$ \\
\hline & $\begin{array}{l}\text { A familiarity of faculty members with research } \\
\text { methodologies, statistical tests, preparation of } \\
\text { questionnaires, etc. is not enough. }\end{array}$ & $28(32.9)$ & $40(47.1)$ & $15(17.6)$ & $2(2.4)$ \\
\hline & $\begin{array}{l}\text { Professors do not have enough skills in using } \\
\text { computer and computer applications. }\end{array}$ & $13(15.3)$ & $37(43.5)$ & $21(24.7)$ & $14(16.5)$ \\
\hline & $\begin{array}{l}\text { Professors do not have enough proficiency in } \\
\text { skills of searching for articles from the Internet, } \\
\text { how to use online journals and library } \\
\text { resources. }\end{array}$ & $13(15.3)$ & $35(41.2)$ & $16(18.8)$ & $21(24.7)$ \\
\hline & $\begin{array}{l}\text { Professors need more skills in writing essays, } \\
\text { preparing posters, and publishing them in } \\
\text { domestic and foreign journals and academic } \\
\text { assemblies inside and outside. }\end{array}$ & $29(34.1)$ & $41(48.2)$ & $6(7.1)$ & $9(10.6)$ \\
\hline & $\begin{array}{l}\text { The knowledge and mastery of professors in } \\
\text { foreign languages are not enough to use foreign } \\
\text { resources in their specialized fields. }\end{array}$ & $19(22.4)$ & $40(47.1)$ & $13(15.3)$ & $13(15.3)$ \\
\hline & $\begin{array}{l}\text { Most professors are not familiar with general } \\
\text { principles of writing and writing research } \\
\text { papers. }\end{array}$ & $14(16.5)$ & $40(51.8)$ & $24(28.2)$ & $3(3.5)$ \\
\hline Total & Scientific barriers & $21(24.7)$ & $34(40.0)$ & $25(29.4)$ & $5(5.9)$ \\
\hline \multirow{5}{*}{ Individual } & $\begin{array}{l}\text { Individualism and unwillingness to participate } \\
\text { in group research are seen in most of the } \\
\text { professors. }\end{array}$ & $21(24.7)$ & $41(48.2)$ & $20(23.5)$ & $3(3.5)$ \\
\hline & $\begin{array}{l}\text { Occasionally, some cases of non-observance of } \\
\text { research ethics and scholarly trust are seen } \\
\text { among scholars. }\end{array}$ & $16(18.8)$ & $34(40.0)$ & $25(29.4)$ & $10(11.8)$ \\
\hline & $\begin{array}{l}\text { Instead of paying attention to health care issues } \\
\text { of the AJA, the idea, topic, and research methods } \\
\text { are often taken from foreign or domestic } \\
\text { research. }\end{array}$ & $26(30.6)$ & $39(45.9)$ & $16(18.8)$ & $4(4.7)$ \\
\hline & $\begin{array}{l}\text { There is no match between the research } \\
\text { priorities of AJA and the faculty members' } \\
\text { interests. }\end{array}$ & $25(29.4)$ & $43(50.6)$ & $14(16.5)$ & $3(3.5)$ \\
\hline & $\begin{array}{l}\text { Professors do not have enough motivation and } \\
\text { interest to do research. }\end{array}$ & $34(40.0)$ & $33(38.8)$ & $13(15.3)$ & $5(5.9)$ \\
\hline Total & Individual barriers & $20(23.5)$ & $53(62.4)$ & $12(14.1)$ & $0(0)$ \\
\hline \multirow{10}{*}{$\begin{array}{l}\text { Organizational- } \\
\text { managerial }\end{array}$} & $\begin{array}{l}\text { The faculty members are hired at the university } \\
\text { regardless of their research ability. }\end{array}$ & $24(28.2)$ & $35(41.2)$ & $23(27.1)$ & $3(3.5)$ \\
\hline & $\begin{array}{l}\text { The steps to accept the article for publishing in } \\
\text { domestic and foreign journals are long and slow. }\end{array}$ & $47(55.3)$ & $29(34.1)$ & $9(10.6)$ & $0(0)$ \\
\hline & $\begin{array}{l}\text { Officials, doctors, and staff at AJA hospitals do } \\
\text { not have enough co-operation with researchers. }\end{array}$ & $22(25.9)$ & $42(49.4)$ & $17(20.0)$ & $4(4.7)$ \\
\hline & $\begin{array}{l}\text { The staff and personnel of the University's } \\
\text { research management are not well responsive. }\end{array}$ & $17(20.0)$ & $36(42.4)$ & $24(28.2)$ & $8(9.4)$ \\
\hline & $\begin{array}{l}\text { The research needs and priorities of the health } \\
\text { care system of AJA are unclear. }\end{array}$ & $22(25.9)$ & $26(30.6)$ & $29(34.1)$ & $8(9.4)$ \\
\hline & $\begin{array}{l}\text { The process of drafting and submitting } \\
\text { proposals and research proposals are not clear } \\
\text { to researchers. }\end{array}$ & $15(17.6)$ & $20(23.5)$ & $36(42.4)$ & $14(16.5)$ \\
\hline & $\begin{array}{l}\text { Doing and submitting research is not } \\
\text { compulsory for professors. }\end{array}$ & $18(21.2)$ & $18(21.2)$ & $29(34.1)$ & $20(23.1)$ \\
\hline & $\begin{array}{l}\text { The quality of students' dissertations is low and } \\
\text { is review articles. }\end{array}$ & $29(34.1)$ & $36(42.4)$ & $13(15.3)$ & $7(8.2)$ \\
\hline & $\begin{array}{l}\text { The results of the University's research are not } \\
\text { being used in improving the health care issues. }\end{array}$ & $42(49.4)$ & $37(43.5)$ & $5(5.9)$ & $1(1.2)$ \\
\hline & $\begin{array}{l}\text { Managers do not provide adequate support for } \\
\text { research activities in the research community. }\end{array}$ & $39(45.9)$ & $36(42.4)$ & $8(9.4)$ & $2(2.4)$ \\
\hline
\end{tabular}




\begin{tabular}{|c|c|c|c|c|c|}
\hline & $\begin{array}{l}\text { The professors will not be adequately informed } \\
\text { about the resources, facilities, and regulations } \\
\text { related to the research. }\end{array}$ & $41(48.2)$ & $34(40.0)$ & $8(9.4)$ & $2(2.4)$ \\
\hline & $\begin{array}{l}\text { The incentive, encouragement and support } \\
\text { system for research by university senior } \\
\text { executives is not sufficient and suitable. }\end{array}$ & $44(51.8)$ & $34(40.0)$ & $4(4.7)$ & $3(3.5)$ \\
\hline & $\begin{array}{l}\text { Personal taste and opinion are applied in the } \\
\text { evaluation and approval of projects and articles. }\end{array}$ & $27(31.8)$ & $35(41.2)$ & $17(20.0)$ & $6(7.1)$ \\
\hline & $\begin{array}{l}\text { No priority is considered to publish the research } \\
\text { papers of professors in the AJA Journal of } \\
\text { Medicine. }\end{array}$ & $30(35.3)$ & $29(34.1)$ & $17(20.0)$ & $9(10.6)$ \\
\hline Total & Managerial-organizational barriers & $24(28.2)$ & $48(56.5)$ & $13(15.3)$ & $0(0)$ \\
\hline $\begin{array}{l}\text { Total research } \\
\text { barriers }\end{array}$ & & $35(41.2)$ & $49(57.6)$ & $1(1.2)$ & $0(0)$ \\
\hline
\end{tabular}

${ }^{\mathrm{a}}$ Values are expresses as No. (\%). 